\title{
THE APPEARANCE OF RENEWABLE ENERGY SOURCES IN THE SETTLEMENT DEVELOPMENT DOCUMENTS OF LOCAL AUTHORITIES IN JÁSZ-NAGYKUN-SZOLNOK COUNTY
}

\author{
BENCE MONYÓK ${ }^{1}$, GÁBOR KOZMA*
}

${ }^{1}$ Department of Social Social Geography and Regional Development Planning, Institute of Earth Sciences, University of Debrecen, Debrecen

*Email: kozma.gabor@science.unideb.hu

Received 1 April 2021, accepted in revised form 10 May 2021

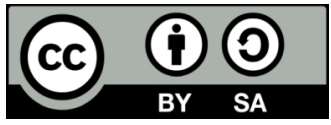

\begin{abstract}
In recent decades, several new trends can be observed in the field of energy management, one of which is the increase of the role of renewable energy sources. As a result of this fact, local authorities in Hungary have also devoted increasing attention to this question in recent years. The first step of their interventions is the drawing up of the appropriate development documents, relying on which specific steps/investments can also take place later. In the spirit of the above, the objective of the present paper is to analyse the development documents of local authorities in Jász-Nagykun-Szolnok County. The most important findings of the study could be summarised as follows. Firstly the Integrated Settlement Development Strategies prepared for the period 2014 to 2020 dealt with the topic of renewable energy sources in much more detail than earlier documents. Secondly from the various renewable energy sources, the development document devoted most attention to solar and geothermal energy and thirdly the appearance of renewable energy sources in the development documents shows a close link with the size of the settlements.
\end{abstract}

Keywords: renewable energy sources, Hungary, Jász-Nagykun-Szolnok County, development concepts of local authorities

\section{Introduction}

In recent decades, several new trends can be observed in the field of energy management, one of which is the increase of the role of renewable energy sources. This process is attributable to several factors. From the point of view of environmental protection (Adefarati, - Bansal, 2017; Bilgili et al., 2016; Ellabban et al., 2014; López-Menéndez, 2014, Zhang et al., 2017), it can be underlined that the widespread use of renewables results in a decrease of the emission of certain pollutants (e.g. CO2). As a second important consideration, we could mention the security of supply: due to the decentralized nature of the systems relying on renewables, they are less exposed to problems resulting from network interruptions (Dinya, 2010, Demirbas et al., 2009; Sebestyén, 2017). Thirdly, the use of renewable energy sources can also play an important role with respect to economic and rural development, since it can contribute to closing the gap between developed and less developed rural areas (Borhanazad et al., 2013; Ekéné Zamárdi - 
Baros, 2004; Koncz - Nagyné Demeter, 2015; Magda, 2011; Michalkó et al., 2017).

Having recognized the importance of this topic, in the last 10 to 15 years, several European Union and Hungarian documents have emphasized the significance of the spread of renewable energy. In the document titled "Renewable Energy Roadmap," published by the European Commission in February 2007, the proposal was put forward that the share of renewables in the total energy consumption of the European Union should reach $20 \%$ by 2020 (European Commission, 2007). The Europe 2020 strategy, published in 2010, reinforced this objective (European Commission, 2010), after which, in January 2018, the European Parliament approved an even more ambitious target of reaching a 35\% share by 2030 (European Parliament, 2018).

At the time of its accession to the European Union, Hungary undertook an obligation to reach a $3.6 \%$ proportion of electricity produced from renewable energy sources, which was already achieved by the mid2000s. In the interest of achieving the target set in the Europe 2020 strategy, Hungary made a commitment to reach a share of $14.6 \%$, and the same target was also included in the document titled Hungary's Action Plan for the Use of Renewable Energy 2010-2020 (NFM, 2011).
As a result of the above, local authorities in Hungary have also devoted increasing attention to this question in recent years. The first step of their interventions is the drawing up of the appropriate development documents, relying on which specific steps/ investments can also take place later. In the spirit of the above, the objective of the present paper is to analyse the development documents of local authorities in JászNagykun-Szolnok County (Fig. 1), in the framework of which we were looking for answers to the following questions:

- What changes over time can be found by comparing the documents produced in the periods between 2007 to 2013, and 2014 to 2020 ?

- What parts of the materials (e.g. analysis of the situation, vision for the future, thematic objectives, concrete projects) deal with renewable energy sources?

- What differences can be observed between the individual settlements?

\section{Material and methods}

In the course of the preparation of the paper, we have analysed the most important settlement development documents of the local authorities (altogether 17 cities - Fig. 2) in the county (the Integrated

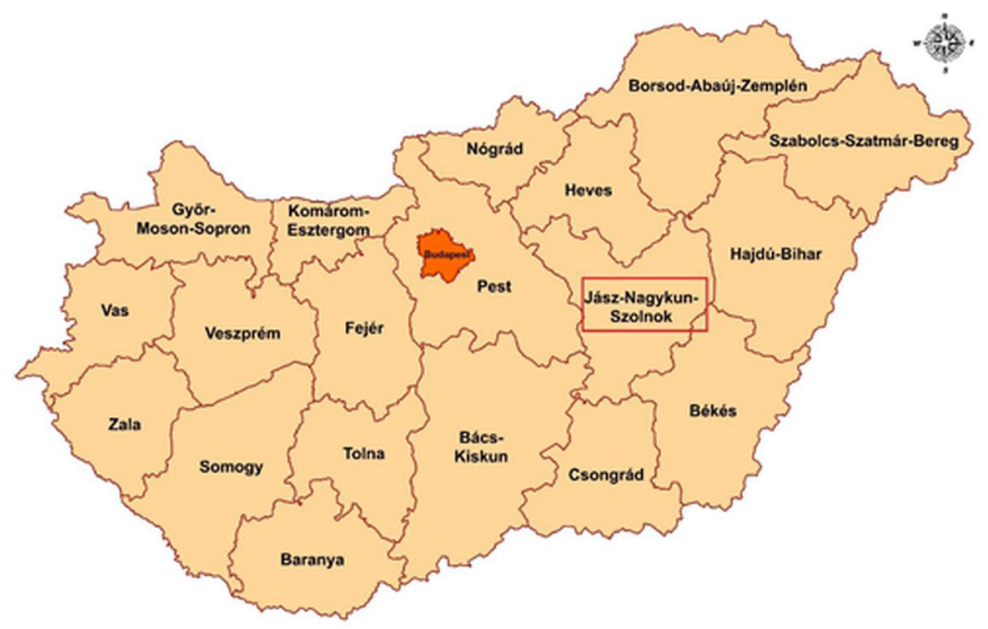

Fig. 1. Location of Jász-Nagykun-Szolnok county in Hungary

(Source: own work) 


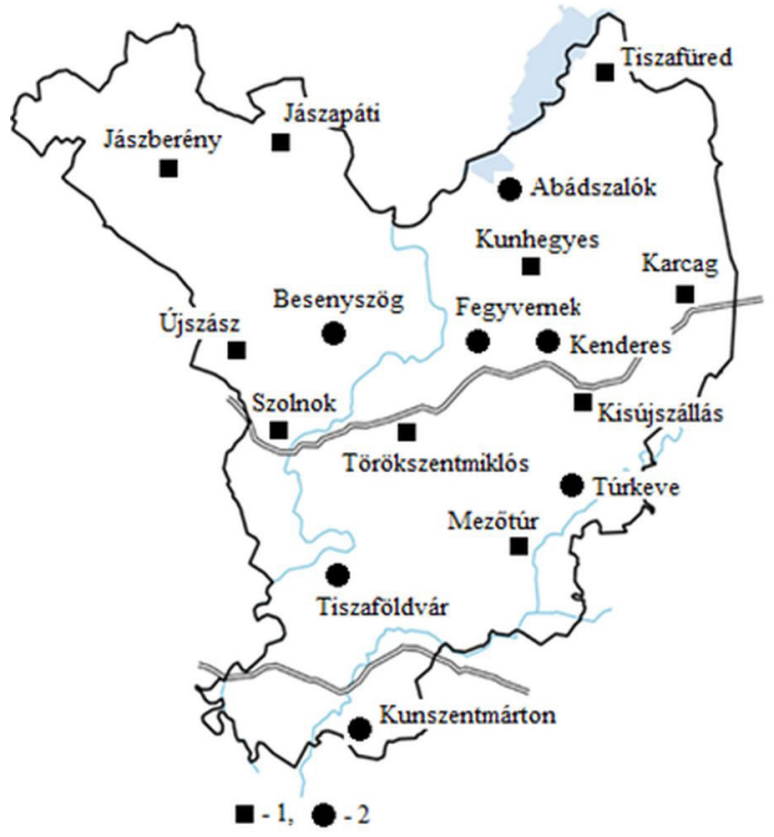

Fig. 2. Geographical location of 17 towns in Jász-Nagykun-Szolnok county examined

1 - both documents (Integrated Urban Development Strategy: 2007-2013; Integrated Settlement Development Strategy: 2014-2020), 2 - only Integrated Settlement Development Strategy (2014-2020)

(Source: own work)

Urban Development Strategy in the period between 2007 and 2013, and the Integrated Settlement Development Strategy between 2014 and 2020). When comparing the two periods, we only analysed those settlements in the case of which both materials were available (altogether 10 settlements); at the same time, when exploring the situation in a given period, those settlements were also included in the scope of the analysis that only prepared one of the documents, typically the Integrated Settlement Development Strategy.

The Integrated Urban Development Strategy fundamentally played an increasingly important role in the spirit of the Leipzig Charter on Sustainable European Cities adopted in 2007, in the second half of that decade (Barta, 2009), and in the 2017-2013 programming period only those settlements had to prepare such a strategy that wanted to receive funding from the urban rehabilitation grants available under the Regional Operational Programmes. The Integrated Settlement Development Strategy is the medium-term development programme aimed at the simultaneous implementation of the environmental, social and economic objectives included in the settlement development concept. In connection with the content of the given documents, there were some common elements (e.g. analysis of the situation, formulation of overall objective, medium-term thematic objectives, neighbourhood objectives, drawing up of anti-segregation programme). The provision of law applicable to the preparation of the latter [Government decree 314/2012 (XI. 8) on the settlement development concept, the integrated settlement development strategy and the settlement planning tools and on the specific settlement planning legislation], at the same time, contained much more detailed rules in many areas (e.g. it regulated more precisely the content of analysis of the situation).

In the course of our research, we examined (and scored) how frequently, in what context, and in which parts of the documents the 
Table 1. The points assigned to different key words in the course of the analysis of the documents concerned (Source: own work)

\begin{tabular}{|c|c|c|}
\hline type of document & items examined & points \\
\hline \multirow{3}{*}{$\begin{array}{l}\text { analysis of the } \\
\text { situation }\end{array}$} & $\begin{array}{l}\text { title of a chapter referring to renewable energy } \\
\text { resources }\end{array}$ & 1 point \\
\hline & occurrence in analysis & $\begin{array}{l}1 \text { point/types, maximum } 3 \\
\text { points }\end{array}$ \\
\hline & $\begin{array}{l}\text { SWOT-analysis: reference to renewable energy } \\
\text { resources }\end{array}$ & $\begin{array}{l}1 \text { point/occurrence, maximum } \\
2 \text { points }\end{array}$ \\
\hline \multirow{4}{*}{ strategy } & occurrence in general goal/vision & 3 points \\
\hline & occurrence as a thematic objective & 2 points \\
\hline & mentioning in document & $\begin{array}{l}1 \text { point/occurrence, maximum } \\
3 \text { points }\end{array}$ \\
\hline & concrete projects & $\begin{array}{l}1 \text { point/project, maximum } \\
2 \text { points/type, maximum } 4 \\
\text { points in total }\end{array}$ \\
\hline
\end{tabular}

words referring to renewable energy sources (renewable energy, alternative energy, solar energy, geothermal energy, biomass, wind energy) appear. On the one hand, multiple occurrences meant a higher score; on the other hand, the same applied when one of the terms was mentioned in the SWOT analysis or in the title of one of the thematic objectives (Table 1).

\section{Results}

The analysis of the appearance of renewable energy sources in the documents concerned reveals a very marked progress
(Table 2). The value of the indicator we calculated increased significantly both in case of the part analysing the current situation and in case of the strategy.

The increasing significance is also well reflected by the following facts:

- In case of the Integrated Urban Development Strategies, renewable energy sources were not mentioned in the document of one local authority (Jászberény), and it also did not appear in the analysis of the current situation or in the strategy parts in the documents of three more local authorities. By contrast, there was

Table 2. The scores reflecting the occurrence of renewable energy sources in the Integrated Urban Development Strategies and the Integrated Settlement Development Strategies (in case of settlements where both documents have been prepared)

\begin{tabular}{cccc}
\hline & analysis of the situation & strategy & total \\
\hline $\begin{array}{c}\text { Integrated Urban Development } \\
\text { Strategy }\end{array}$ & 16.0 & $35.0\left(18.0^{*}\right)$ & $51.0\left(34^{*}\right)$ \\
$\begin{array}{c}\text { Integrated Settlement Development } \\
\text { Strategy }\end{array}$ & 43.0 & $48,0\left(22.0^{*}\right)$ & $91.0\left(66.0^{*}\right)$ \\
$\begin{array}{c}\text { Integrated Settlement Development } \\
\text { Strategy }\end{array}$ & 71.0 & $72.0\left(33.0^{*}\right)$ & $143.0\left(105.0^{*}\right)$ \\
\hline
\end{tabular}

* - score without concrete projects, 1 - local authorities that also prepared Integrated Urban

Development Strategies, 2 - settlements that only prepared Integrated Settlement Development Strategies

Source: own calculation based on the documents (see the method in Table 1) 
only one single Integrated Settlement Development Strategy prepared for the period between 2014 and 2020 that did not mention renewable energy sources in at least one part of the document (Kisújszállás - analysis of the situation).

- In the SWOT analyses, renewable energy sources are only mentioned on 5 occasions in the Integrated Urban Development Strategies and 9 times in the Integrated Settlement Development Strategies in case of settlements where both documents have been prepared;

In our opinion, the following reasons (may) stand behind the changes described above:

- Local authorities are also increasingly aware of the significance of renewable energy sources (e.g. cost savings), and this fact is reflected in the documents prepared.

- The provision of law pertaining to Integrated Settlement Development Strategies (already mentioned above) defines in detail the topics to be analysed in the foundation examination, according to which separate sections were to be devoted to energy management (several local authorities already described the situation concerning renewables in this chapter) and to the use of renewable energy sources. (Out of the materials of the ten local authorities that could be involved in the comparison over time, eight had such a subchapter, even though their levels of detail were quite varied across the documents.)
- In their Integrated Settlement Development Strategies, the local authorities mentioned quite a many concrete projects in comparison with earlier documents, which could be explained by two reasons. On the one hand, this is how the leaders of the settlements wanted to present the links between their plans with the development concepts put forward in the various operational programmes; and on the other hand, the local population also wanted to see what concrete projects are planned to be implemented in the upcoming period. In case of renewable energy sources, both of these factors were important; however, the first one can be considered to be more dominant.

The examination of the concrete projects appearing in the documents offers one of the best opportunities for comparing the significance of the different types of renewable energy sources (Table 3 ), since these already show the clear commitment of the local authorities. On the basis of the available data, the first preference of the settlements was solar energy (this means solar thermal collectors and to a lesser extent photovoltaic power plants), with the second place occupied by geothermal energy and the third place by biomass. The special role of solar energy can be fundamentally explained by three facts. Firstly, the natural conditions in the county are quite suitable for the use of this type of renewable energy: the annual number of sunshine hours exceeds 1,950 hours on the largest part of the county (Fig. $3)$.

Table 3. The types of renewable energy mentioned in the concrete projects Source: own calculation based on the documents

\begin{tabular}{ccccc}
\hline & solar energy & geothermal energy & biomass/biogas & wind energy \\
\hline $\begin{array}{c}\text { Integrated Urban } \\
\begin{array}{c}\text { Development Concept (10 } \\
\text { documents) }\end{array}\end{array}$ & 4 & 4 & 4 & 1 \\
$\begin{array}{c}\text { Integrated Settlement } \\
\text { Development Concept (17 } \\
\text { documents) }\end{array}$ & 12 & 7 & 5 & 1 \\
\hline
\end{tabular}




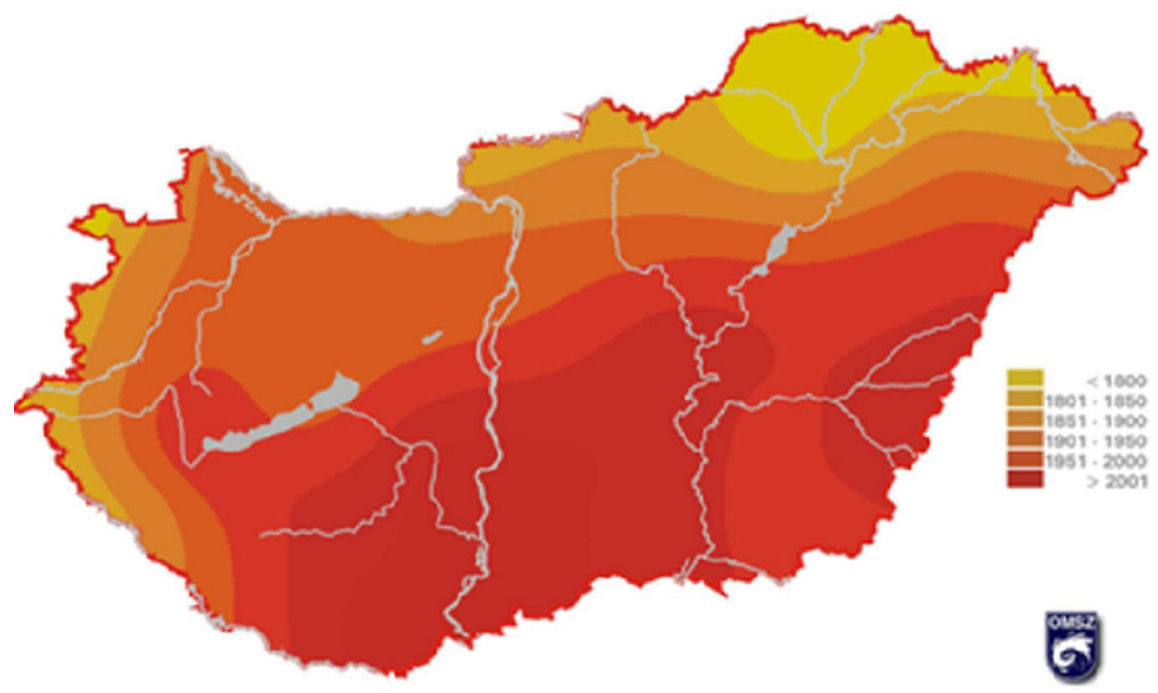

Fig. 3. The average annual sunshine duration (hours) in Hungary

Source: www.omsz.hu

Secondly, a significant part of the European Union funds available in the 2007-2013 and 2014-2020 (2007-2013: Environment and Energy Operational Programme - Increase of the use of renewable energy sources priority axis, 2014-2020: Environmental and Energy Efficiency Operational Programme Increasing energy efficiency, using renewable energy sources priority axis), supported investments related to the use of solar energy, and local authorities confirmed their willingness to apply for such funding in the form of planning concrete projects. The funds available for the abovementioned priority axes increased significantly, and probably this is what also explains the increasing

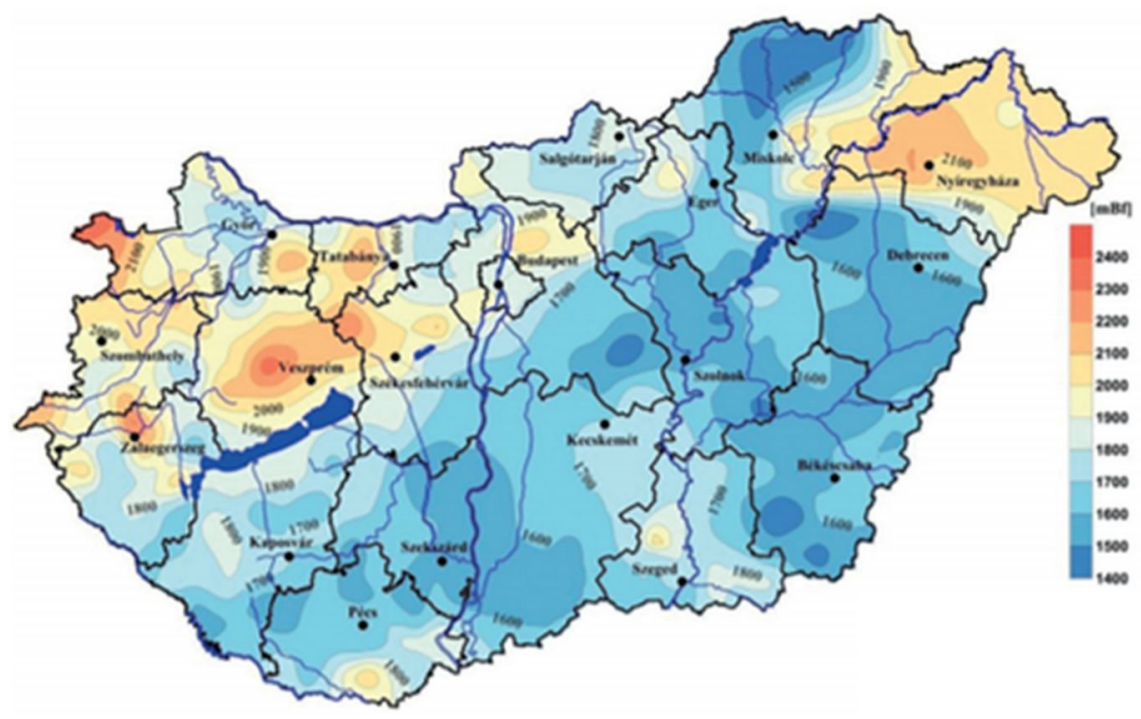

Fig. 4. Geo-isothermal depth distribution map of Hungary for $90^{\circ} \mathrm{C}$

Source: Tóth, 2019 
Table 4. The scores reflecting the appearance of renewable energy sources in the documents, shown as a function of settlement size (the average of the settlements in the given size category; due to the low number of settlements in the individual categories, these values could not be calculated for the Integrated Urban Development Strategies).

\begin{tabular}{cc}
\hline & Integrated Settlement Development Strategy \\
\hline less than 5,000 inhabitants & 7.3 \\
$5,000-10,000$ inhabitants & 7.7 \\
$10,000-20,000$ inhabitants & 9.1 \\
more than 20,000 inhabitants & 9.8 \\
\hline
\end{tabular}

number of concrete projects. Thirdly, the official position of the national government, as declared in recent years, also put solar energy in the centre (this is partly what the significant EU funding was also related to).

The second place occupied by geothermal energy can also be traced back to natural reasons: the geothermal gradient is rather low in a significant part of the county, which means that thermal water reservoirs can be found relatively close to the surface that can also be used well for energy production (Fig. 4). Biomass/biogas is close behind geothermal energy in the third position, the possible reason for this is the significant role played by agricultural production in the county, which constitutes the basis of this type of renewable energy source. The role of wind energy can be considered minimal, which is partly attributable to natural reasons (lower wind speeds) and partly to the less positive attitude of the government to this type of renewable energy.

As regards the factors influencing the appearance of renewable energy sources in the documents, one of the most important is the size of the settlement (Table 4). In all likelihood, this can be explained by the fact that settlements with larger populations have more significant financial resources, and as a result, they are able to devote more funds for this purpose (e.g. providing the own contribution in case of various grants), and this is also reflected in the development materials.

\section{Conclusions}

The most important findings of the study could be summarised as follows:

- The Integrated Settlement Development Strategies prepared for the period 2014 to 2020 dealt with the topic of renewable energy sources in much more detail than earlier documents, which fact can be explained, in addition to the local governments becoming more conscious, by the changes in the statutory requirements and the increase in grant opportunities.

- From the various renewable energy sources, the development document devoted most attention to solar and geothermal energy; at the same, due to the economic structure of the county, biomass/biogas can also be considered to be important.

- The appearance of renewable energy sources in the development documents shows a close link with the size of the settlements.

\section{Acknowledgements}

The work/publication is supported by the EFOP3.6.1-16-2016-00022 project. The project is cofinanced by the European Union and the European Social Fund. 


\section{References}

Adefarati, T. - Bansal, R.C. (2017): Reliability and economic assessment of a microgrid power system with the integration of renewable energy resources. Applied energy, 206: 911933.

Barta, Gy. (2009): Integrált városfejlesztési stratégia: a városfejlesztés megújítása [Integrated Urban Development Strategy: Renewal of the Urban Development]. Tér és Társadalom 23(3): 1-12.

Borhanazad, H. - Mekhilef, S. - Saidur, R. Boroumandjazi, G. (2013): Potential application of renewable energy for rural electrification in Malaysia. Renewable Energy 59: 210-219.

Bilgili, F. - Koçak, E. -Bulut, Ü. (2016): The dynamic impact of renewable energy consumption on CO2 emissions: a revisited Environmental Kuznets Curve approach. Renewable and Sustainable Energy Reviews 54: 838-845.

Ellabban, O. - Abu-Rub, H. -Blaabjerg, F. (2014): Renewable energy resources: Current status, future prospects and their enabling technology. Renewable and Sustainable Energy Reviews 39: 748-764.

European Commission (2007): Renewable Energy Road Map Renewable energies in the 21st century: building a more sustainable future. Communcation from the Commission tot he Council and European Parliament. COM(2006) 848, Brussels

European Commission (2010): EUROPE 2020 - A strategy for smart, sustainable and inclusive growth. Communcation from the Commission. COM(2010) 2020, Brussels

European Parliament (2018): Amendments adopted by the European Parliament on 17 January 2018 on the proposal for a directive of the European Parliament and of the Council on the promotion of the use of energy from renewable sources

Demirbas, M.F. - Balat, M. - Balat, H. (2009): Potential contribution of biomass to the sustainable energy development. Energy Conversion and Management 50(7): 1746-1760

Dinya, L. (2010): Biomassza-alapú energiatermelés és fenntartható energiagazdálkodás

[Biomass-based Energy Production and Sustainable Energy Management]. Magyar Tudomány 171(8): 912-925.

Ekéné Zamárdi, I. -Baros, Z. (2004): A megújuló energiaforrások felhasználásának társadalmi vonatkozásai a világban, Európában és hazánkban [Social aspects of the use of renewable energy sources in the world, in Europe and in Hungary]. MSZET kiadványai 2: 113-123.

Koncz, G. - Nagyné Demeter, D. (2015): Megújuló energia projektek közösségfejlesztő szerepe [Community development role of renewable energy projects]. Economica 8(4/2): 142-151.

López-Menéndez, A.J. -Pérez, R. -Moreno, B. (2014): Environmental costs and renewable energy: re-visiting the environmental Kuznets curve. Journal of environmental management 145: 368-373.

Magda, R. (2011): A megújuló energiaforrások szerepe és hatásai a hazai agrárgazdaságban [Role and impacts of the renewable energy sources in Hungarian agriculture]. Gazdálkodás 55(6): 575-588.

Michalkó, G. - Lontai-Szilágyi Zs. - Kiss, K. - Martonné Erdős, K. (2017): A megújuló energia szerepe a falusi turizmus és a magyarországi falvak modernizációjában [Role of the renewable energy sources in modernization of Hungarian tourism and villages]. Turizmus Bulletin 17(12): $35-44$

NFM (2011): Megújuló energia. Magyarország megújuló energia hasznosítási cselekvési terve, 2010-2020 [Renewable energy. Hungary's Action Plan for the Use of Renewable Energy 2010-2020]. Nemzeti Fejlesztési Minisztérium, Budapest

Sebestyén, T.T. (2017): Székelyföld fahulladékainak energiapotenciálja lehet a régió energiaszektorának hajnala [The wood waste, as energy potential, is the initial point of the seklerland region's energy sector]? Journal of Central European Green Innovation 5(3): 95124.

Tóth, A. (2019): Magyarország geotermikus felmérése a Magyar Energetikai és Közműszabályozási Hivatal geotermikus projektjei tükrében [Geothermal Survey of Hungary as Regards of the Hungarian Energy \& Utilities Regulatory Agency Geothermal Projects] Magyar Tudomány 180(12): 1822-1833.

Zhang, B. - Wang, B. - Wang, Z. (2017): Role of renewable energy and non-renewable energy consumption on EKC: evidence from Pakistan. Journal of Cleaner Production 156: 855-864. 